\title{
実地震記録に基づく基礎入力動評価 \\ EVALUATION OF FOUNDATION INPUT MOTIONS BASED ON OBSERVED SEISMIC WAVES
}

\author{
栗本 修*, 井口道雄** \\ Osamu KURIMOTO and Michio IGUCHI
}

\begin{abstract}
Most of experimental studies on soil-structure interaction have been focused on the evaluation of impedance functions that represents the relationship between the dynamic response of rigid foundation and external forces. However, it is important to obtain the foundation input motions as well as the impedance functions in order to evaluate properly the seismic response of soil-structure system. This paper presents an approximate but practical method to evaluate the foundation input motions based on sparsely. observed earthquake ground motions. The characteristics of the foundation input motions are also discussed. The comparison between the results obtained by the proposed method and the numerically calculated results shows good coincidence in lower frequencies. The method can be applied to practical purpose to evaluate observationally the foundation input motions for structures before construction.
\end{abstract}

Keywords : dynamic soil-structure interaction, embedded foundation, foundation input motion, earthquake observation, axisymmetric finite element method 動的相互作用, 埋め込み基䃈, 基䃈入力動, 地震篗測, 軸対称有限要素法

\section{1.はじめに}

地盤と構造物の動的相互作用問題において基本となる 物理量はインピーダンス関数と基礎入力動である。イン ピーダンス関数および基礎人力動の評価に関して, 解析 的研究が先行して発展したが, 近年, 実験精度も向上し 解析理諭の検証に耐えうる実証的な研究1) -5)も多くなっ てきた。その多くは起振機を構造物上に設置し強制外力 を与える振動実験であり，その結果得られる構造物の応 答性状にはおのずから「慣性の相互作用」の特性のみが 含まれている。したがって，適切な試験方法を選択すれ ば比較的容易にインピーダンス関数を実験から抽出する ことができる。

一方, 動的相互作用問題のもう一つの特性である「入 力の相互作用」すなわち基礎入力動を評価することは強 制振動試験では不可能である。これに対し, 地盤一構造
物連成系に外部からの入力である地震波が入射したとき の系の応答を観測し； その観測結果から基礎入力動を評 価する研究(6),7)も行なわれている。しかし，そこで得られ る地震応答結果には「慣性の相互作用」と「入力の相互 作用」が混在しており, 両者を分離して評価するために は，インピーダンス関数を別途評価しておくこと，加え て構造物の慣性力を正確に把握する必要がある。このた め, 計測点数などの観測システムが大がかりになる。

本研究では，まず，インピーダンス関数は実験または 解析によってあらかじめ求められていて既知量であるこ とを前提とし, 観測值としては地震時の地盤の変位応答 のみから基礎入力動を求める近似評価法を提案し, 次 に，構造物のない状態で採取された地盤の地震観測記録 を用いて，その地盤に構造物を建設した場合に想定され る基礎入力動を近似評価法にしたがって求めた。本提案
* 㑣大林組技術研究所 工修

** 東京理科大学理工学部 工博
Technical Research Institute, Obayashi Corporation, M. Eng. Faculty of Science and Engineering, Science University of Tokyo, Dr. Eng. 
手法の特徴は，必要とする地震観測の情報としては地盤 の変位のみであり, 構造物を含めた地震観測に比べ比較 的小さな観測網で基礎入力動を評価することができる点 にある。

\section{2.地盤応答を用いた基礪入力動の評価方法}

図一1に示すような埋め込み基礎に対する基礎入力動は $\mathrm{Luco}^{8}{ }^{8}$ による表現を書き直して, 次式のように表わされ る。

$$
\begin{aligned}
\left\{U^{*}\right\} & =[K]^{-1} \int_{S}[A(\bar{X})]^{T}[Z]\left\{u^{f}(\bar{X})\right\} d S \\
& -[K]^{-1} \int_{S}[A(\bar{X})]^{T}\left\{\tau_{n}^{f}(\bar{X})\right\} d S, \bar{X} \in S
\end{aligned}
$$

ここに,

$$
\begin{aligned}
& \left\{U^{*}\right\}=\left\{\Delta_{x}^{*} ; \Delta_{y}^{*}, \Delta_{z}^{*}, \Phi_{x}^{*}, \Phi_{y}^{*}, \Phi_{z}^{*}\right\}^{T}
\end{aligned}
$$

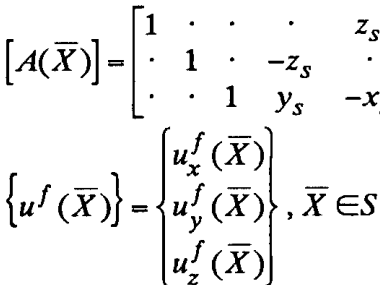

$$
\begin{aligned}
& \left\{\tau_{n}^{f}(\bar{X})\right\}=\left\{\begin{array}{l}
\tau_{n x}^{f}(\bar{X}) \\
\tau_{n y}^{f}(\bar{X}) \\
\tau_{n z}^{f}(\bar{X})
\end{array}\right\}, \bar{X} \in S
\end{aligned}
$$

である。Sは基礎と地盤の接触面を表わし， $\bar{X}\left(x_{s}, y_{s}, z_{s}\right)$ は基礎と地盤との仮想境界面の座標を表わす。また， $[K]$ は基礎の底面中心に集約されたインピーダンス関数， $[Z]$ は基礎と地盤の接触面における動的剛性マトリクスであ り, 次の関係にある。

$$
[K]=\int_{S}[A(\bar{X})]^{T}[Z][A(\bar{X})] d S
$$

また， $u_{x}^{f}, u_{y}^{f}, u_{z}^{f}$ ，および $\tau_{n x}^{f}, \tau_{n y}^{f}, \tau_{n z}^{f}$ は自由地盤内の境界 面上での変位および応力の成分を表す。なお， $\boldsymbol{\tau}_{n}^{f}$ は境界 面の外部領域に対し，外向きに応力を定義する。

これに対し，筆者の一人 ${ }^{91}$ はインピーダンス関数が別途 求められていることを前提に，(1)式の右辺第一項につい て基礎位置に相当する自由地盤の変位に平均化操作を施 し，基礎入力動の近似評価式として(3)式を導いた。

$$
\left\{U^{*}\right\} \approx[H]^{-1} \int_{S}[A(\bar{X})]^{T}\left\{u^{f}(\bar{X})\right\} d S
$$

$$
-[K]^{-1} \int_{S}[A(\bar{X})]^{T}\left\{\tau_{n}^{f}(\bar{X})\right\} d S, \bar{X} \in S
$$

ここに,

$$
[H]=\int_{S}[A(\bar{X})]^{T}[A(\bar{X})] d S .
$$

上式を用いれば，インピーダンス関数を既知として, 自由地盤の変位および，応力の情報をもとに基礎入力動 を求めることができる。しかしながら，実際の地震観測 において地盤中の応力を精度良く計測することは困難で ある。そこで，以下では，(3)式を変形し，観測値として

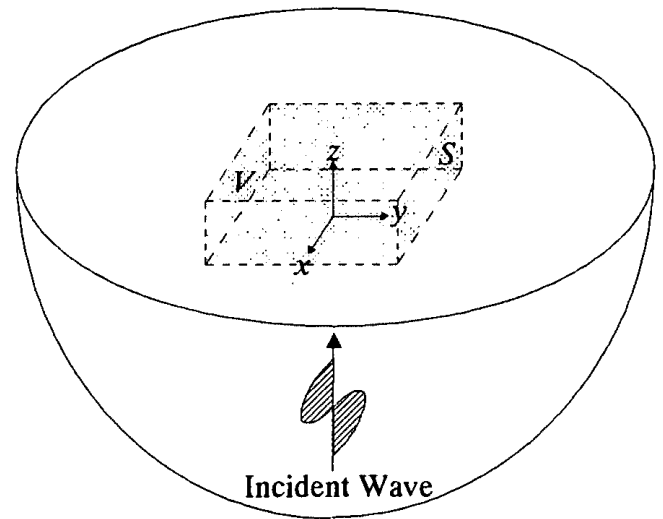

図一1＼cjkstart座標軸および仮想境界面

は自由地盤の変位のみによる基礎人力動の評価式を導出 する。

まず，(3)式の右辺第2項の積分を次のようにおく。 $\left\{T^{f}\right\}=\int_{S}[A(\bar{X})]^{T}\left\{\tau_{n}^{f}(\bar{X})\right\} d S, \bar{X} \in S$

(5)式において

$$
\left\{T^{f}\right\}=\left\{F_{x}^{f}, F_{y}^{f}, F_{z}^{f}, M_{x}^{f}, M_{y}^{f}, M_{z}^{f}\right\}^{T}
$$

と成分表示すれば， $F_{x}^{f}, F_{y}^{f}, F_{z}^{f}$ は地震動入射によって自 由地盤内に生じる応力の座標軸方向の合力, $M_{x}^{f}, M_{y}^{f}, M_{z}^{f}$ は各座標軸に関する合モーメントを表して いる。(2-2)，(2-4)式を(5)式に代入して，合力および合 モーメントの表現式に分離すれば次のようになる。

$$
\begin{aligned}
& \left\{\begin{array}{l}
F_{x}^{f}(\bar{X}) \\
F_{y}^{f}(\bar{X}) \\
F_{z}^{f}(\bar{X})
\end{array}\right\}=\int_{S}\left\{\begin{array}{l}
\tau_{n x}^{f}(\bar{X}) \\
\tau_{n y}^{f}(\bar{X}) \\
\tau_{n z}^{f}(\bar{X})
\end{array}\right\} d S, \bar{X} \in S \\
& \left\{\begin{array}{l}
M_{x}^{f}(\bar{X}) \\
M_{y}^{f}(\bar{X}) \\
M_{z}^{f}(\bar{X})
\end{array}\right\}=\int_{S}\left[\begin{array}{ccc}
\cdot & -z_{S} & y_{S} \\
z_{S} & \cdot & -x_{S} \\
-y_{S} & x_{S} & \cdot
\end{array}\right]\left[\begin{array}{l}
\tau_{n x}^{f}(\bar{X}) \\
\tau_{n y}^{f}(\bar{X}) \\
\tau_{n z}^{f}(\bar{X})
\end{array}\right\} d S, \bar{X} \in S
\end{aligned}
$$

$F_{x}^{f}, F_{y}^{f}, F_{z}^{f}, M_{x}^{f}, M_{y}^{f}, M_{z}^{f}$ は地盤内の仮想境界の外側領 域に作用する応力の合力, 合モーメントを表わすことに 留意すれば，運動量および角運動量の平衡法則 ${ }^{10), 11)}$ り，(6)，(7)式は次のように書ける。

$$
\begin{aligned}
& \left\{\begin{array}{l}
F_{x}^{f} \\
F_{y}^{f} \\
F_{z}^{f}
\end{array}\right\}=-\int_{V} \rho\left\{\begin{array}{l}
\ddot{u}_{x}^{f}(X) \\
\ddot{u}_{y}^{f}(X) \\
\ddot{u}_{z}^{f}(X)
\end{array}\right\} d V, X \in V \\
& \left\{\begin{array}{l}
M_{x}^{f} \\
M_{y}^{f} \\
M_{z}^{f}
\end{array}\right\}=-\int_{V} \rho\left[\begin{array}{ccc}
\cdot & -z & y \\
z & : & -x \\
-y & x & \cdot
\end{array}\right]\left[\begin{array}{l}
\ddot{u}_{x}^{f}(X) \\
\ddot{u}_{y}^{f}(X) \\
\ddot{u}_{z}^{f}(X)
\end{array}\right\} d V, X \in V .
\end{aligned}
$$

ここで， $\ddot{u}_{x}^{f}, \ddot{u}_{y}^{f}, \ddot{u}_{z}^{f}$ は自由地盤内での加速度成分, Vは仮 想境界面で囲まれた領域， $x, y, z$ は領域 $V$ 内の座標， $\rho$ は質 量をそれぞれ表わす。

時間に関して調和振動を仮定すれば，(8)，(9)式は次の 
ように書き直すことができる。

$$
\begin{aligned}
& \left\{\begin{array}{l}
F_{x}^{f} \\
F_{y}^{f} \\
F_{z}^{f}
\end{array}\right\}=\omega^{2} \int_{V} \rho(X)\left\{\begin{array}{l}
u_{x}^{f}(X) \\
u_{y}^{f}(X) \\
u_{z}^{f}(X)
\end{array}\right\} d V, X \in V \ldots \ldots \ldots \ldots \ldots . . .(10) \\
& \left\{\begin{array}{l}
M_{x}^{f} \\
M_{y}^{f} \\
M_{z}^{f}
\end{array}\right\}=\omega^{2} \int_{V} \rho(X)\left[\begin{array}{ccc}
\cdot & -z & y \\
z & \cdot & -x \\
-y & x & \cdot
\end{array}\right]\left[\begin{array}{l}
u_{x}^{f}(X) \\
u_{y}^{f}(X) \\
u_{z}^{f}(X)
\end{array}\right\} d V, X \in V
\end{aligned}
$$

(10)，(11)式を(5)式に代入すれば,

$$
\left\{T^{f}\right\}=\omega^{2} \int_{V} \rho(X)[A(X)]^{T}\left\{u^{f}(X)\right\} d V, X \in V
$$

したがって，(3)式は次式となる。

$$
\begin{aligned}
& \left\{U^{*}\right\} \approx[H]^{-1} \int_{S}[A(\bar{X})]^{T}\left\{u^{f}(\bar{X})\right\} d S \\
& \quad-\omega^{2}[K]^{-1} \int_{V} \rho(X)[A(X)]^{T}\left\{u^{f}(X)\right\} d V, \bar{X} \in S, X \in V
\end{aligned}
$$
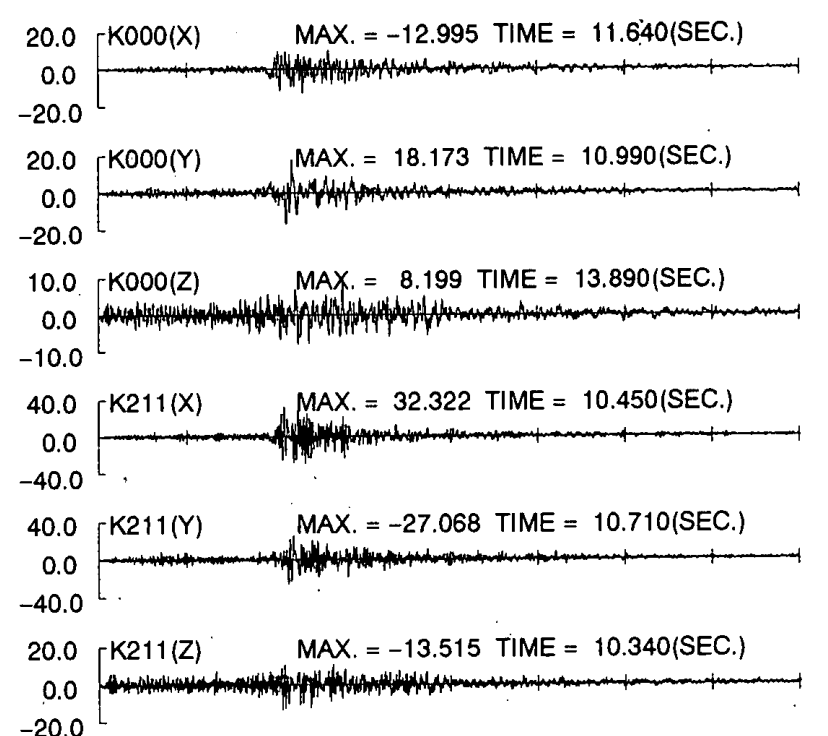

$-20.0$

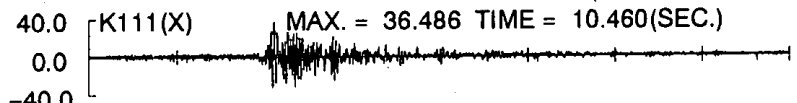

$-40.0$
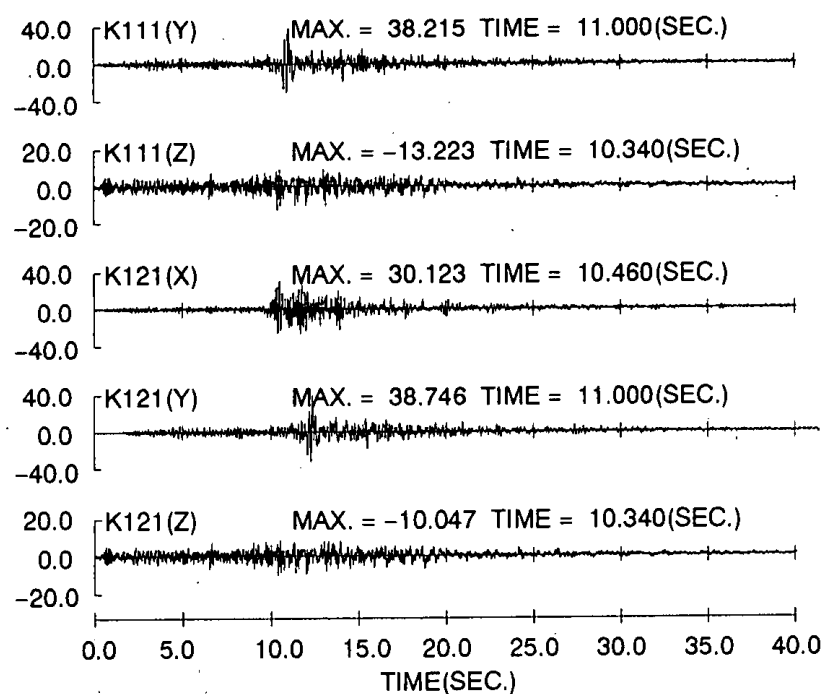
TIME(SEC.)
(13)式はインピーダンス関数を別途求めておけば; 自 由地船内の变位のみの情報を利用して基礎入力動を算定 することができ，(3)式に比べより実用的といえる。

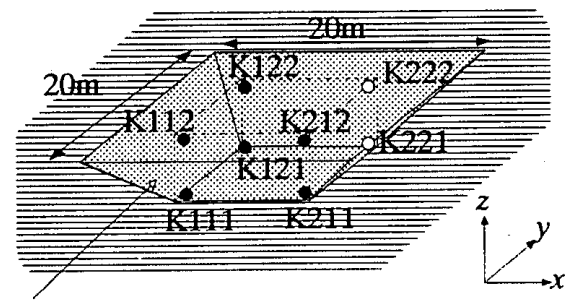

埋め戻し土

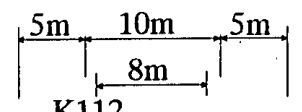

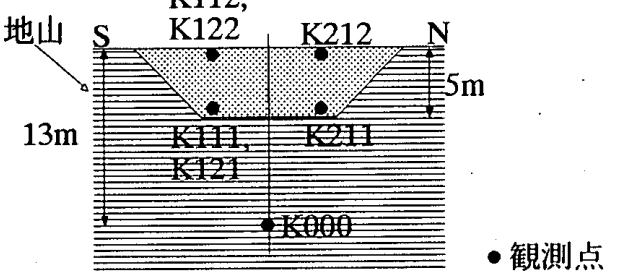

(すへて $\mathrm{x}(\mathrm{NS}), \mathrm{y}(\mathrm{EW}), \mathrm{z}(\mathrm{UD}) の 3$ 成分を記録) 図一2 地震観測位置

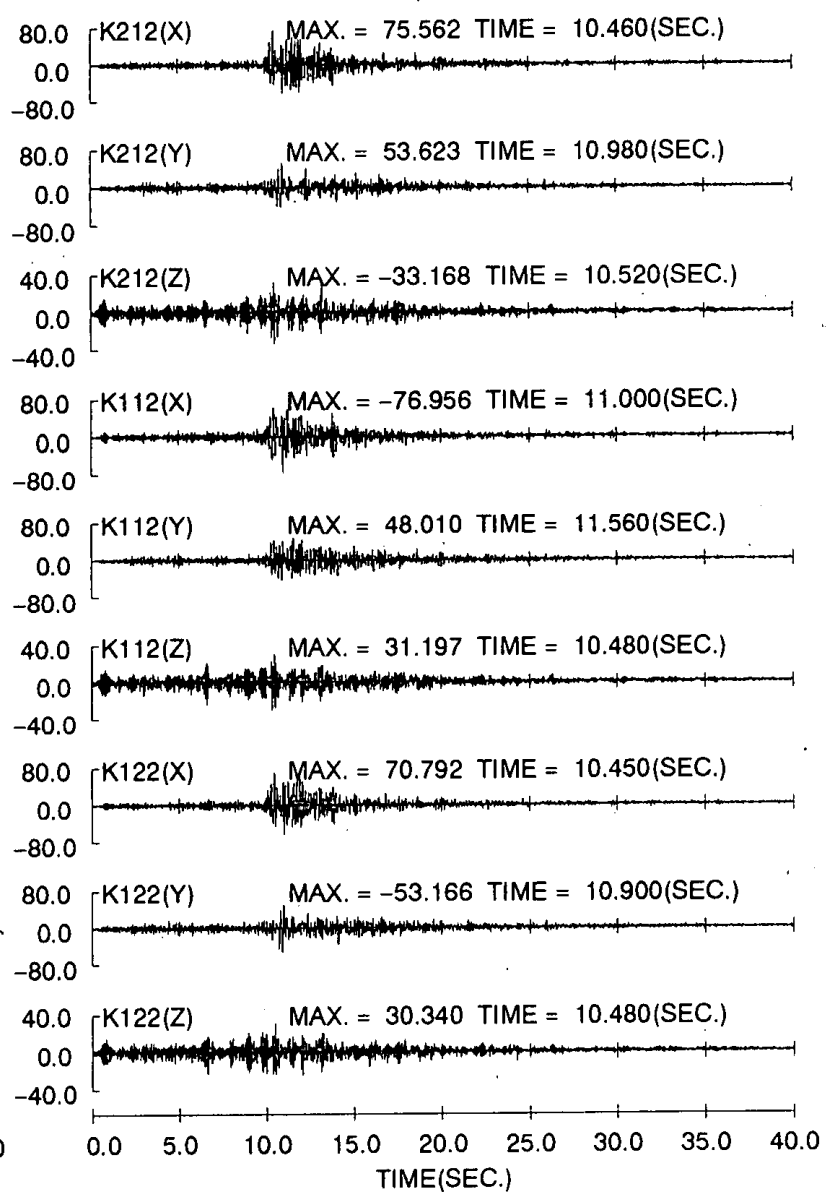

図一3 観測地点の加速度波形 （単位：gal） 


\section{3.地盤系の地震観測}

\section{1地震観測の概要 ${ }^{12), 13)}$}

図ー2に示すように, $x(\mathrm{NS}), y(\mathrm{EW}), z(\mathrm{UD})$ の成分の 地震動を地船内の三角格子上の6点およびG.L. $-13 \mathrm{~m}$ の深 い位置に設置された地震計により観測している。地震計 が埋設されている地盤はローム(せん断波速度 90〜 $125 \mathrm{~m} / \mathrm{sec}$ ), 砂岩(せ九断波速度 $220 \sim 280 \mathrm{~m} / \mathrm{sec}$ )および角 嘫岩(せん断波速度290 1200m/sec.)よりなる成層地盤を

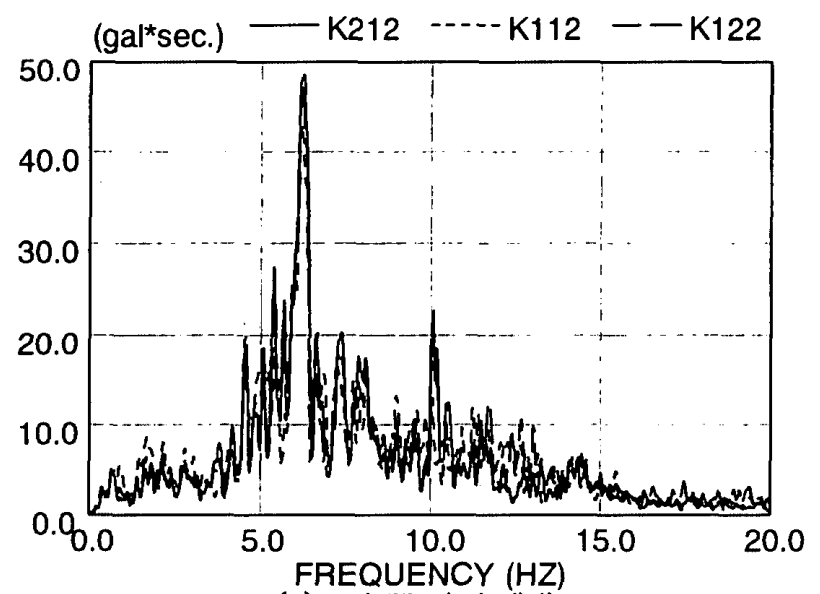

（a）水平 $\times$ 方向成分

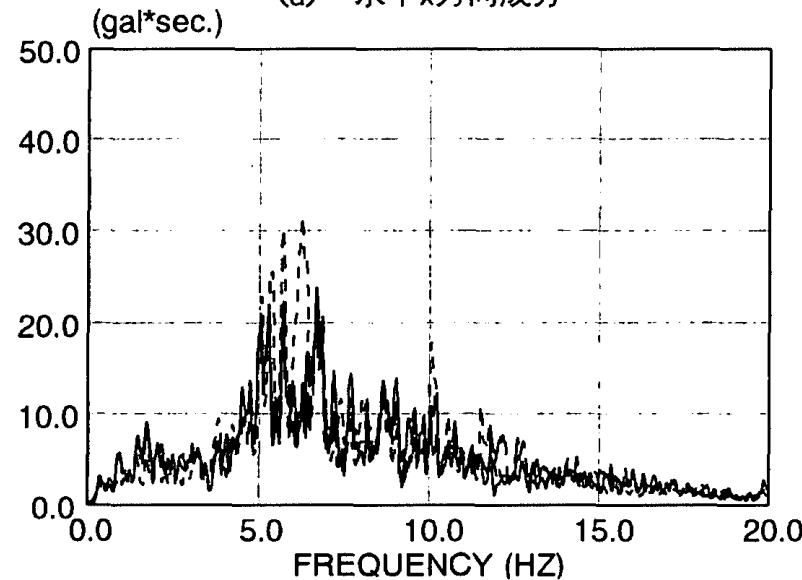

(b) 水平y方向成分

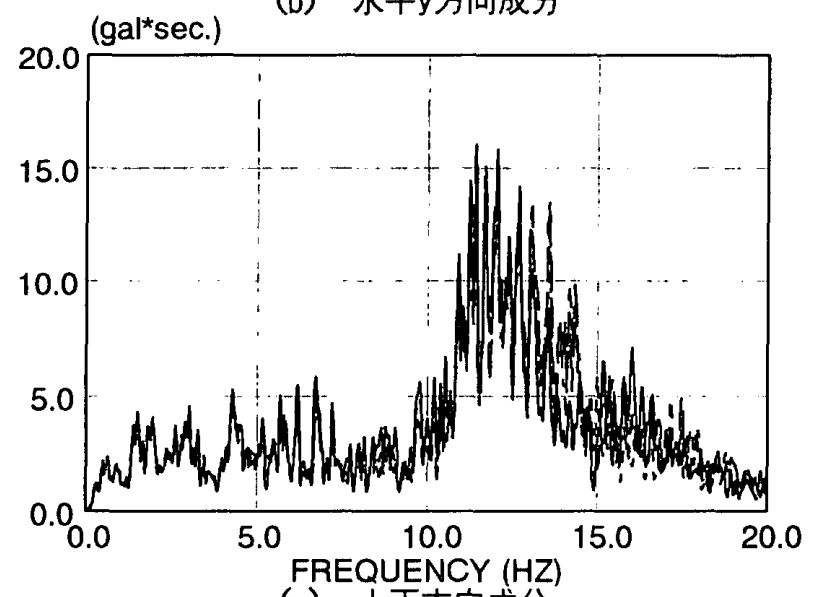

(c) 上下方向成分

図-4＼cjkstart観測地震のフーリェスペクトル
掘削し, 山砂で埋め戻された(せん断波速度が $130 \mathrm{~m} / \mathrm{sec} に$ なるように埋め戻しの施工管理されている)地盤である。

本研究で使用した各観測点における観測地震の波形を 図一3に示す。この地震のマグニチュードはM6.5, 震源 深さは $90 \mathrm{~km}$, 震央距離は $54 \mathrm{~km}$ である。また, 地表面で の最大加速度は水平 $\mathrm{x}$ 方向で約 $75 \mathrm{gal}$, 水平 $\mathrm{y}$ 方向で約 $50 \mathrm{gal}$ ，上下方向で約30galである。

図ー4には地表面の観測点でのフーリエスペクトルを示 す。各スペクトルにはバンド幅 $0.1 \mathrm{~Hz}$ のParzen Windowを かけてある。主要動が卓越する方向と思われる水平 $x$ 方向 成分では平面的な位置の異なる3点のスペクトル形状がほ ほそろっているが, 水平y方向成分ではK112点が他の2点 之振幅が山となる5７Hzの範囲でかなり異なっている。 上下方向成分についても3点の応答がそろっており，S波 が鉊直入射したと考えられる。

\section{2地盤応答のシミュレーション解析}

まず，観測地点における地盤の地震時応答性状を把握 するため，S波の銛直入射を仮定し，軸対称FEMを用い て地盤応答のシミュレーション解析を行なった。

(1)解析モデルおよび解析地盤定数

観測地点および周辺の地表面の状況を考虑して，解析 モデルを図ー5のように設定した。その際，掘削，埋め戻 しの平面形状は矩形であるが軸対称FEMでは面積等価な 円形に置換して解析した。

観測地点で行ったボーリング調査により地質とその地 層構成はほぼ成首であることがわかっている。埋め戻し 前後の弾性波探査とボーリング孔を利用して行ったPS検 層結果をもとに表一1〜表-2に示す地盤定数を解析に用 いた。表中の番号は図ー5に示す要素，地層に対応してい る。なお，掘削の際に地盤を乱したおそれがあることと 根伐り底での弾性波探查結果から，表一1に示すように(8) のS波速度と密度の值は(5)より小さく設定した。 (2)伝達関数

図一6に観測記録と解析結果の比較を示す。観測記録に おいては，G.L.-13mの位置の記録(K000)を基準とした観 測点K212の伝達関数を示し，解析においては観測点に対 応する節点応答から伝達関数を求めた。ボーリング調查 結果に基ついて，根伐り底の(8)を除いて，他をそのまま モデル化したCASE-Aによる解析結果はおおむ的観測と の対応が良いが， $6.5 \mathrm{~Hz}$ 付近のピーク振幅がやや小さい。 埋め戻し土のせん断波速度と密度から6.5Hzのピークは埋 め戻し土の 1 次共振振動数と推測される。周辺地盤の最上 層は風化した表土であることを考慮して，密度を小さめ に変更したCASE-Bでは周波数特性はあまり変化しない がピーク振幅はより観測結果に近いものとなった。これ は周辺地盤がその質量により，埋め戻し部分の震動を拘 束しているためと考えられる。 
表－1 地盤定数 (CASE-A)

\begin{tabular}{|c|c|c|c|c|c|}
\hline $\begin{array}{c}\text { 番 } \\
\text { 号 }\end{array}$ & $\begin{array}{c}\text { 密度 } \\
r\left(\mathrm{t} / \mathrm{m}^{3}\right)\end{array}$ & $\begin{array}{c}\text { S波速度 } \\
\mathrm{Vs}(\mathrm{m} / \mathrm{s})\end{array}$ & $\begin{array}{c}\text { ポアソ比 } \\
\nu\end{array}$ & $\begin{array}{c}\text { 减衰定数 } \\
\mathrm{h}(\%)\end{array}$ & $\begin{array}{c}\text { 層厚 } \\
\mathrm{H}(\mathrm{m})\end{array}$ \\
\hline (1) & 1.7 & 90 & 0.350 & 5 & 1.0 \\
\hline (2) & 1.7 & 125 & 0.395 & 5 & 1.5 \\
\hline (3) & 1.8 & 220 & 0.352 & 5 & 1.5 \\
\hline (4) & 1.9 & 280 & 0.206 & 5 & 1.0 \\
\hline (5) & 1.9 & 280 & 0.206 & 5 & 3.1 \\
\hline (6) & 1.9 & 440 & 0.328 & 3 & 4.7 \\
\hline (7) & 2.1 & 1080 & 0.412 & 3 & 23.4 \\
\hline (8) & 1.8 & 180 & 0.355 & 5 & 0.6 \\
\hline (11) & 1.7 & 110 & 0.3 & 5 & 1.0 \\
\hline (12) & 1.7 & 120 & 0.3 & 5 & 1.0 \\
\hline (13) & 1.7 & 130 & 0.3 & 5 & 1.0 \\
\hline (4) & 1.8 & 140 & 0.3 & 5 & 1.0 \\
\hline (15) & 1.8 & 150 & 0.3 & 5 & 1.0 \\
\hline
\end{tabular}

表 -2 地盤定数 (CASE-B)

\begin{tabular}{|c|c|c|c|c|c|}
\hline $\begin{array}{l}\text { 番 } \\
\text { 号 }\end{array}$ & $\begin{array}{c}\text { 密度 } \\
\gamma\left(\mathrm{tf} / \mathrm{m}^{3}\right)\end{array}$ & $\begin{array}{l}S \text { 波速度 } \\
\mathrm{Vs}(\mathrm{m} / \mathrm{s})\end{array}$ & 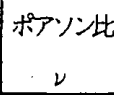 & $\begin{array}{c}\text { 減衰定数 } \\
\mathrm{h}(\%)\end{array}$ & $\begin{array}{l}\text { 層厚 } \\
\mathrm{H}(\mathrm{m})\end{array}$ \\
\hline & 1.3 & 90 & 0.350 & 5 & 1.0 \\
\hline
\end{tabular}

(他の地盤定数は表 -1 に同じ)

\section{4. 地靃観測記録を用いた基礞入力動の検討}

\section{1 地盤内の变位分布の表現}

(13)式を用いて基礎入力動を算定する場合，自由地盤

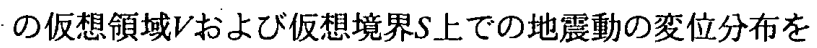
求める必要がある。

本研究で対象としている地盤では数点での観測記録が あるので，それらを代表点として地盤内部の変位分布を 表現する。

図一2に示したように，地盤内の三角格子上の6点にお いて地震動の $x, y, z$ の方向の変位成分を観測している。ま ず, 図中の○印で示す仮想点における変位が次のように 表わされると仮定する。

$$
\begin{aligned}
& \left\{u_{221}^{f}\right\}=C_{1}\left\{u_{211}^{f}\right\}+C_{2}\left\{u_{111}^{f}\right\}+C_{3}\left\{u_{121}^{f}\right\} \\
& \left\{u_{222}^{f}\right\}=C_{1}\left\{u_{212}^{f}\right\}+C_{2}\left\{u_{112}^{f}\right\}+C_{3}\left\{u_{122}^{f}\right\}
\end{aligned}
$$

(14)式における係数 $\mathrm{C}_{\mathrm{i}}(\mathrm{i}=1$ 1 3)は同一滐さにおける3観測 点K111,K211,K121からK221，観測点K112,K212,K122 からK222の変位をそれぞれ推定するための係数であり， 次のような場合が想定できる。

(1) $\mathrm{C}_{1}=\mathrm{C}_{2}=\mathrm{C}_{3}=1 / 3$

3観測点の平均值が仮想点を加えた4点の平均值に等し いとした場合。

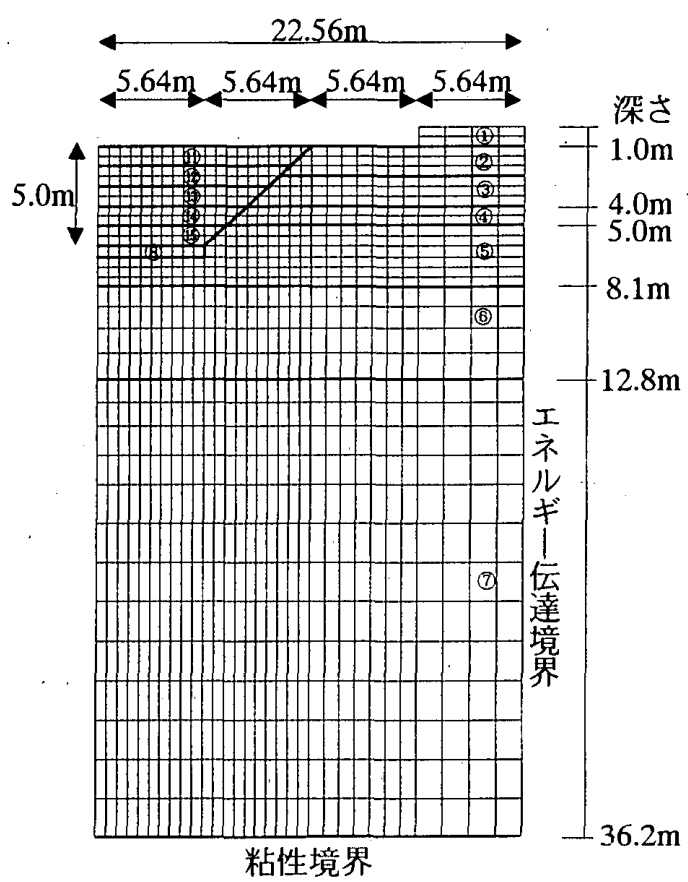

図ー5 軸対称FEMの解析モデル

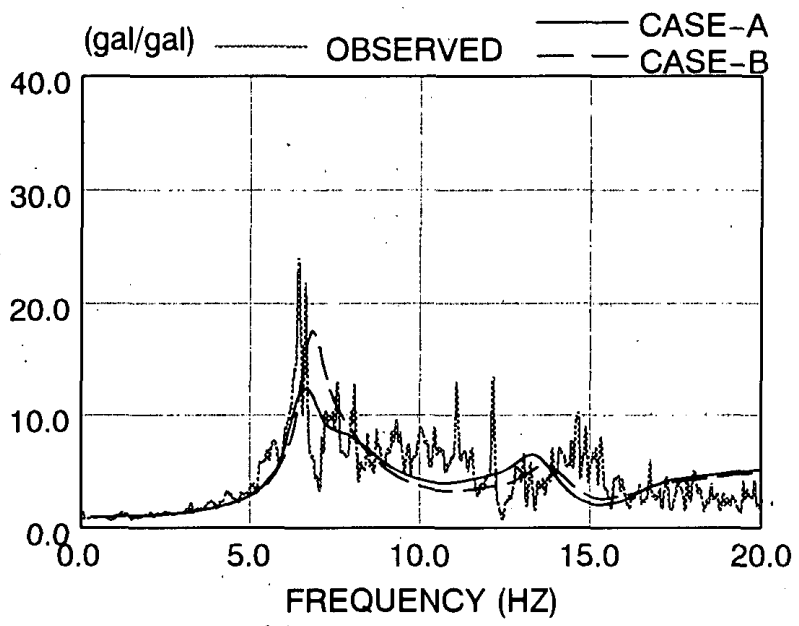

(a) $x$ 方向水平成分

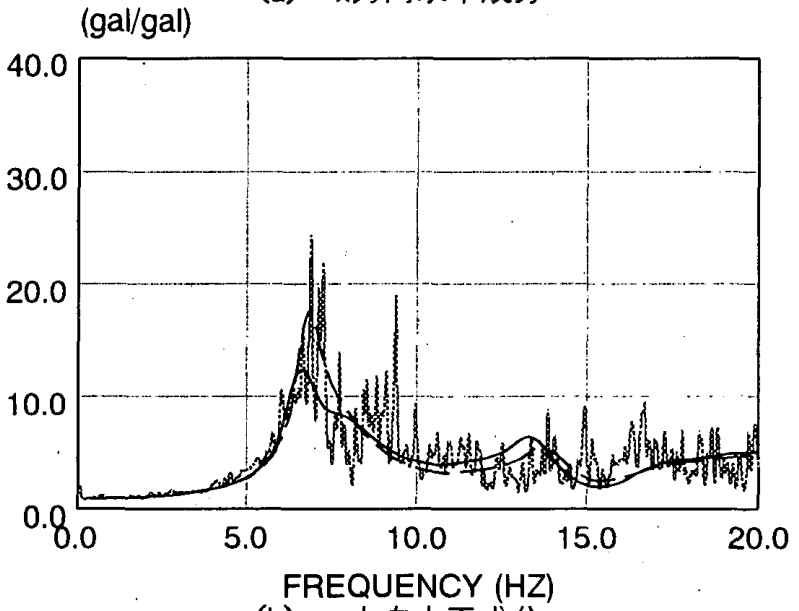

(b) $y$ 方向水平成分

図一6 地盤の伝達関数の比較 
(2) $\mathrm{C}_{1}=\mathrm{C}_{3}=1, \mathrm{C}_{2}=-1$

対角位置にある2点の平均値が互いに等しいとした場 合。これはまた，3観測点での変位から構成される平面 上に仮想点での変位がのるとした場合に相当する。

(3) $\mathrm{C}_{1}=\mathrm{C}_{3}=1 / 2, \mathrm{C}_{2}=0$

仮想点K221に隣接する2点 $(\mathrm{K} 211, \mathrm{~K} 121)$ の平均値が仮 想点の変位に等しいとした場合。

屯し, 各観測点での地盤条件が同じで, 地震動が銛直 入射するものとすれば上記のいずれも同一の結果を与え る。本論では(2)の場合について結果を示したが, (1)，(3) の場合についても別途, 検討を行ない基礎入力動の特性 はほとんど変わらないことを確認してある。

上記の仮想点を含めた地盤内の格子上の 8 点から, 地盤 内の点 $(x, y, z)$ の地震動による変位を次式で表現する。

$$
\left\{u^{f}(x, y, z)\right\}=\sum_{k=1}^{2} \sum_{j=1}^{2} \sum_{i=1}^{2}\left\{u_{i j k}^{f}\right\} \Lambda_{i j k}(x, y, z)
$$

ここで, $\Lambda_{i j k}(x, y, z)$ は内捚関数で, $x, y, z$ それぞれの関 数の積の形で表わすことにする。すなわち，

$$
\Lambda_{i j k}(x, y, z)=\phi_{x i}(x) \cdot \phi_{y j}(y) \cdot \phi_{z k}(z) \cdots
$$

また, $\phi_{x i}(x) \cdot \phi_{y j}(y) \cdot \phi_{z k}(z)$ は

$$
\left\{\begin{array}{l}
\phi_{x 1}(x)=\frac{x-x_{2}}{x_{1}-x_{2}}, \phi_{x 2}(x)=\frac{x-x_{1}}{x_{2}-x_{1}} \\
\phi_{y 1}(y)=\frac{y-y_{2}}{y_{1}-y_{2}}, \phi_{y 2}(y)=\frac{y-y_{1}}{y_{2}-y_{1}} \\
\phi_{z 1}(z)=\frac{z-z_{2}}{z_{1}-z_{2}}, \phi_{z 2}(z)=\frac{z-z_{1}}{z_{2}-z_{1}}
\end{array}\right.
$$

のように与えられる。ここで, $\left(x_{1}, y_{1}, z_{1}\right),\left(x_{1}, y_{1}, z_{2}\right)$ は それぞれ観測点の座標を表わし，たとえば，観測点K212 の座標は $\left(x_{2}, y_{1}, z_{2}\right)$ というように観測点を表わす数值を その点の座標と対応させている。

(15)式を(13)式に代入すれば，観測記録を用いて基礎入 力動を求めることができる。

\section{2基礶入力動の検討}

本節では，観測地点に図ー7に示すような無質量剛基礎 を想定し，その基礎入力動を求める。基礎形状は一辺が $8 \mathrm{~m}$ 正方形で，埋め込み深さは埋め戻し土の厚さと同じ $5 \mathrm{~m}$ とした。

\section{(1)インピーダンス関数}

2章で述へた地盤応答の観測記録を用いて基礎入力動を 算定するにはインピーダンス関数が既知であることを前 提としている。観測地点においては, 地震観測以外の加 振試験等を行なっていないので実験的にインピーダンス 関数を求めることができない。そこで，本研究では軸対 称FEMを用いてインピーダンス関数を求め, これを利用 することとした。

インピーダンス解析のモテルは図ー8に示すように, 3 章で行った地盤の伝達関数のシミュレーション解析に用
いたモデに埋め込み基礎を想定し，地盤の替わりに無 質量剛基礎を付加してある。解析ケースは表-1，表一2の 地盤定数に対するCASE-AおよびCASE-Bである。図一 9にインピーダンス関数の水平成分，回転成分および水平 一回転連成成分を示す。

インピーダンス関数について, CASE-A，CASE-Bの 両解析ケースの差異は小さく, 水平, 回転およびその連 成成分のいずれも20Hzにいたるまでほほ同等の振動数特 性を示している。インピーダンス解析では基礎のごく近 傍の地盤の影響が大きいため, 一部周辺地盤の密度が異 なるだけの両解析ケースでは当然の結果といえる。

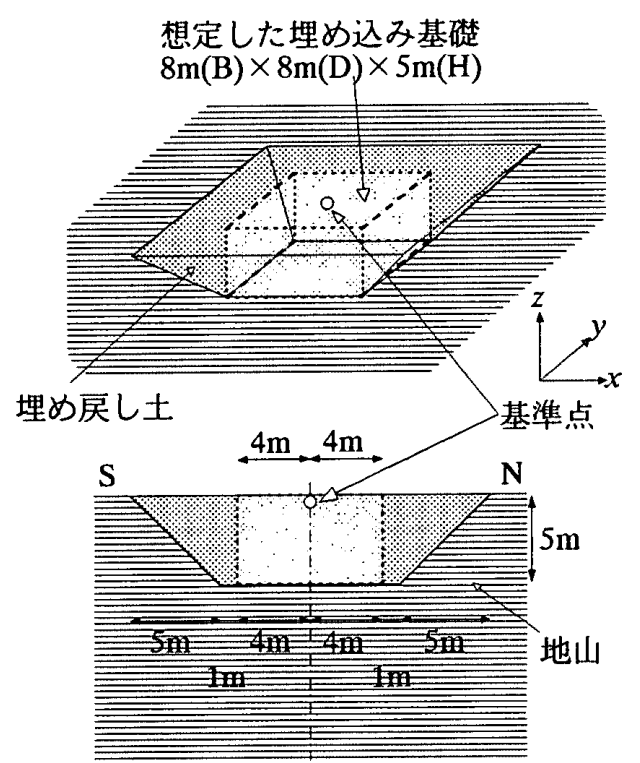

図ー7 想定した基砹と周辺地盤の関係

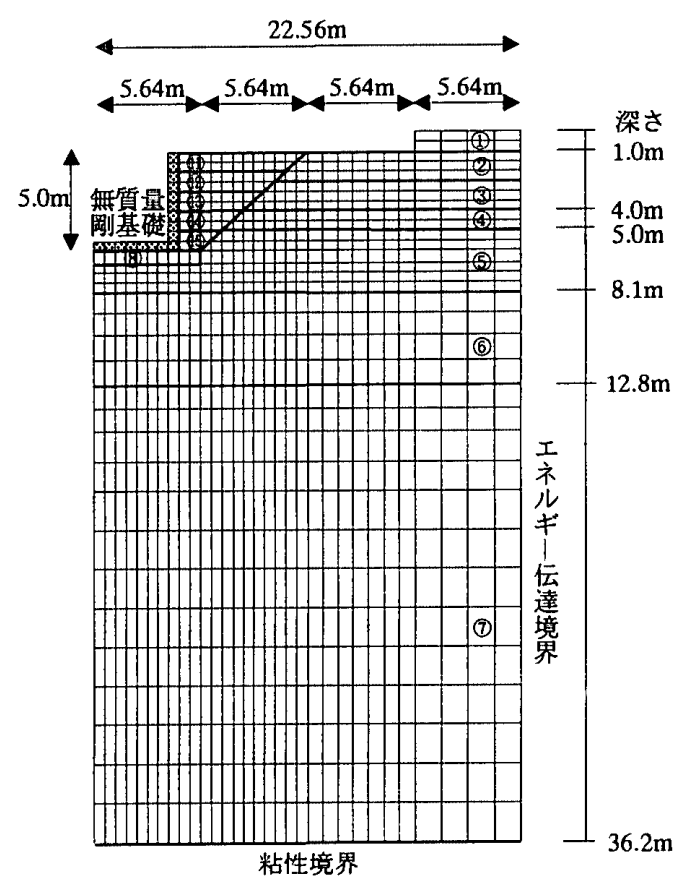

図ー8 インピーダンス解析モデル 


\section{（2）基礎入力動}

観測記録から基䃈入力動を求める際に必要となるイン ピーダンス関数は, CASE-Aの地盤定数について軸対称 FEMを用いて計算した結果を利用した。

図一10に観測記録から算定された基礎入力動を軸対称 FEMによる解析結果と比較して示す。ただし，観測記録 による結果は(15)式により推定される図ー7に○印で示す 点での地盤応答を用いて基準化してある。軸対称FEMで はインピーダンス解析と同一のモデを用いて無質量剛 基礎の地震時応答を求め. 先に行なった地盤のみの地震

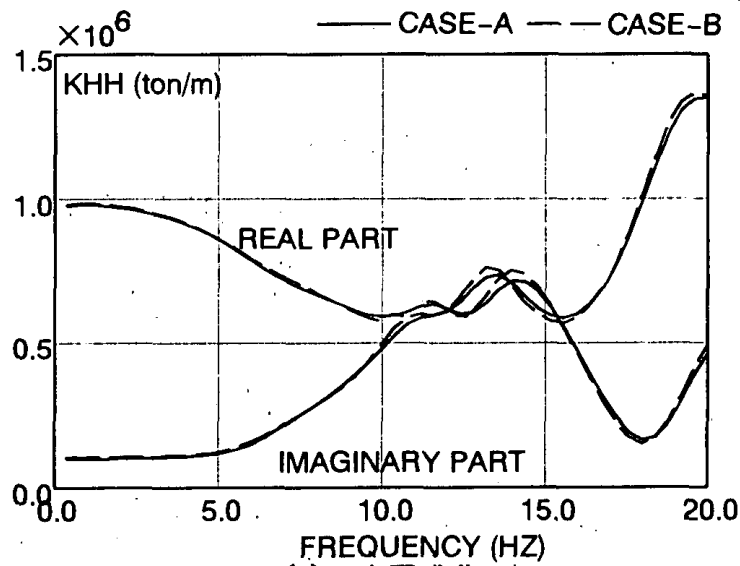

（a）水平成分

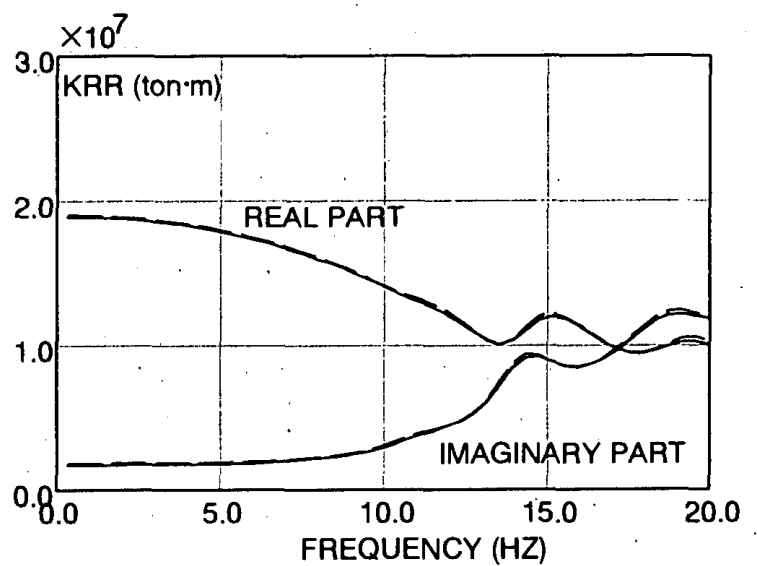

(b) 回転成分

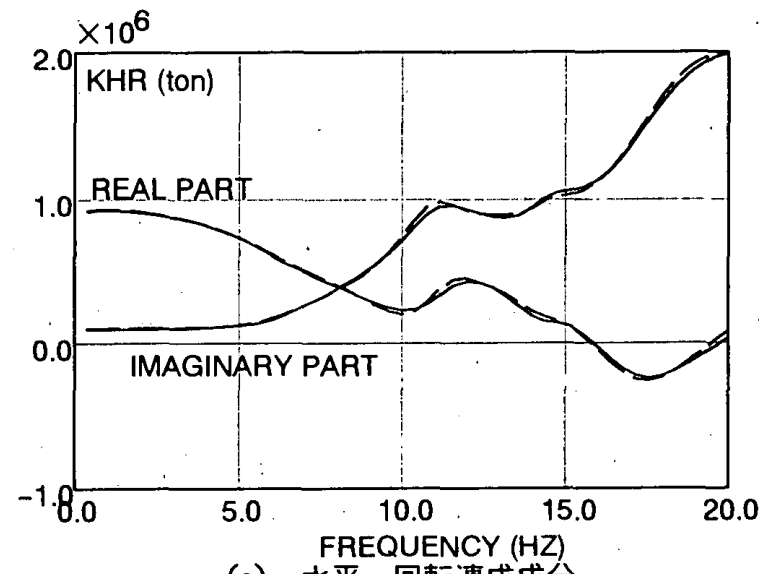

（c）水平一回転連成成分

図ー9 軸対称FEMによるインピーダンス関数
時応答を用いて基準化してある。

まず，観測記録より得られた基礎入力動について検討

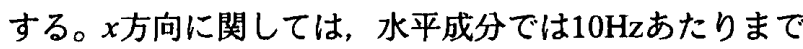
振幅が減少し，その後増加している。回転成分では，振 動数の增加とともに振幅が大きくなる傾向が明瞭に現わ れている。これらは埋め込み基礎の入力動として現われ る特性であり, 既往の研究結果14),15) とも整合する。水平 $y$ 方向に関しても $x$ 方向之ほぼ同椂の傾向が読み取れる。 これは， $x$ およびy方向の成分波形が，同一種類で同一方 向からの人射地震波によるものであることを暗示してい る。

次に, 軸対称FEMによる解析結果と比較してみると， 観測値に比へ解析の方が，水平成分の振幅の落ちる振動 数が低くなっていることや観測值で谷となる10Hzで解析 值が盛り上がるなど若干，傾向が異なっている。この差 異は軸対称FEM解析では地盤掘削形状を円形とし，さら に基礎は円筒形を想定することとなり観測結果の想定と 異なること，観測值に基つく基礎入力動の結果にも以下 に述へるような精度上の問題があることが理由と考えら れる。すなわち，本論文で用いた地震観測網では観測点 が少ないため，(15) (17)式に示すように地盤内の変位分 布を1次関数で近似せざるを得なかった。したがって，高 次モードの地盤震動による基礎人力動への寄与分を無視 することになっており，特に，高振動数域ではその影響 が大きく現われたものと思われる。

しかしながら，解析による振幅の絶対値，振動数に対 する変化の傾向は水平，回転成分とも，おおむね観測記 録より求めた特性に対応している。

\section{5.まとめ}

本論文では, インピーダンス関数については実験また は解析によってあらかじめ求められていて既知量である ことを前提とし，構造物に対する基䃈入力動を観測值と しては地盤の変位観測記録のみを用いて評価する近似手 法を提案した。また，実地震記録から埋め込み基礎の入 力動を算定し, 従来, 解析的に指摘されていた有効入力 の特性を確認した。

さらに，本研究の特徴は次のようにまとめることがで きる。剛基礎の入力動を実証的に求める方法としては, インピーダンス関数を既知として，地盤一構造物連成系 の地震時に観測された基礎の変位および基礎を含む上部 構造物の慣性力をもとに評価する方法がある。この方法 は地震観測から現存する構造物に対する基礎入力動を評 価することができるという利点を持つが，地盤と構造物 の系全体の大規模な地震観測が必要となる。これに対 し，本提案手法はインピーダンス関数を既知とする前提 条件は同様であるが，構造物を含まない自由地盤系のみ 


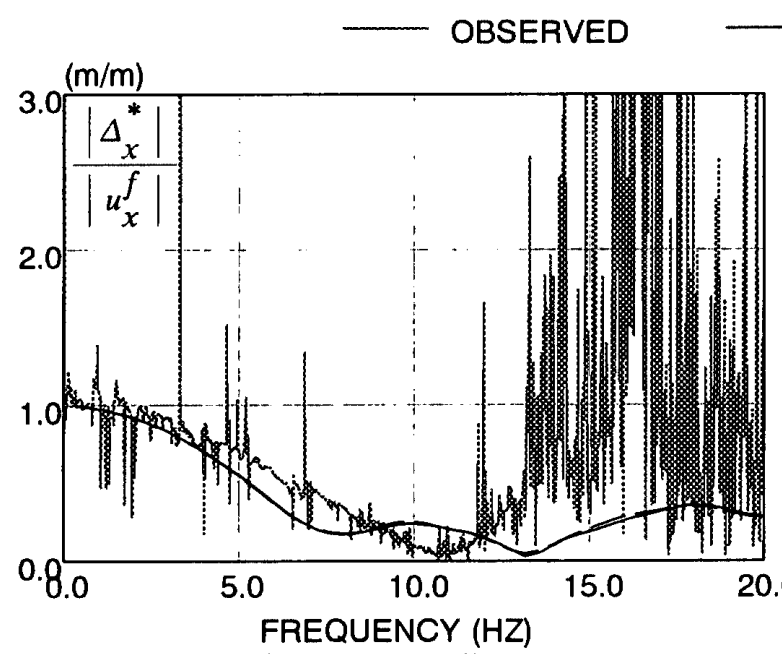

CASE-A - CASE-B

（a） $x$ 方向水平動成分

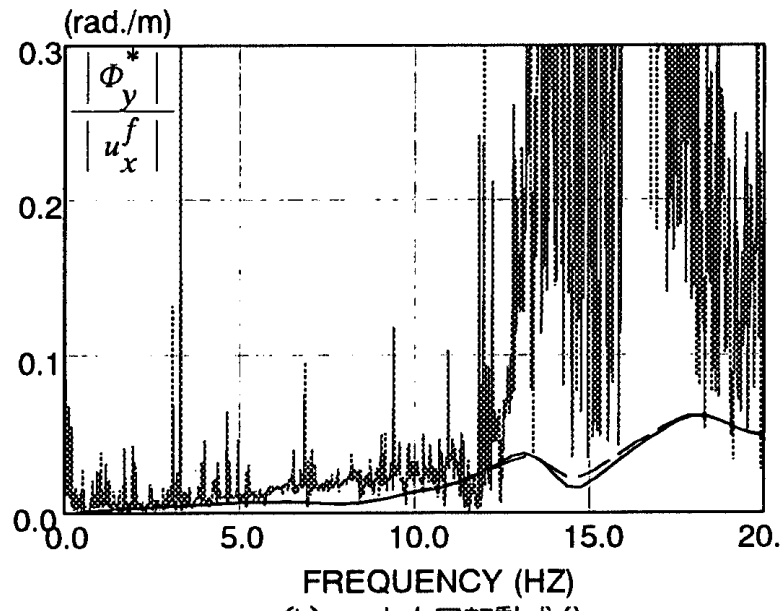

(b) $x$ 方向回転動成分 $(\mathrm{m} / \mathrm{m})$

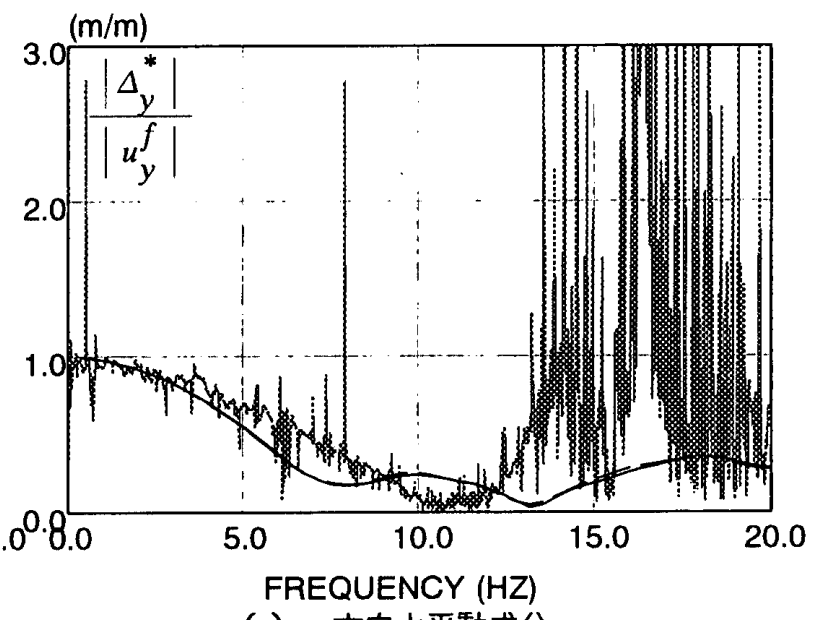

(c) $y$ 方向水平動成分

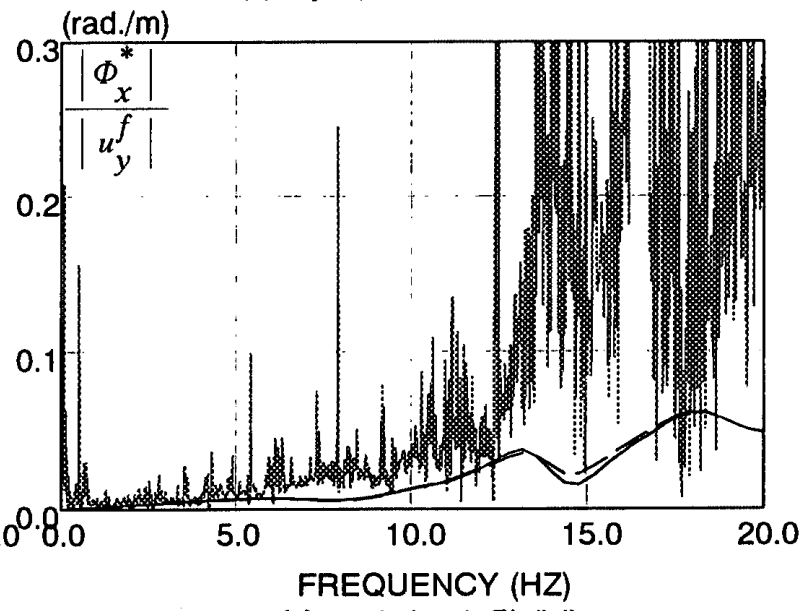

図一10 基礞入力動の比較

の小規模な観測結果をもとに基礎入力動を推定できる。 また，建設予定地において地震計を地盤中に設置し，得 られた観測記録から構造物への入力動を建物の建設前に 推定でき，実設計面への応用も可能と考えられる。

\section{謝辞}

本研究を進めるにあたり，侏大林組技術研究所・角田 智彦博士には多くの面から支援していただいた。ここ に，深甚の謝意を表します。

\section{参考文献}

1）井口道雄他，"大型模型による原子妒建屋と地盤の動的相互作用試 験 (その19)基礎単独試験結果の検討(共振 - 位相曲線, 動的地 盤ばね)", pp.261 - 262, 日本建築学会大会学術講演梗概集,1987

2) 大塚康弘他, "原子炉建屋の埋込子震動効果試験・実地盤上試験 (その3)共振 - 位相曲線と動的地盤ばね (A1,A2,A3試験)", pp.1069-1070, 日本建筑学会大会学術講演梗概集,1989

3）宮本裕司他, "原子炉建屋の埋込み震動効果試験・実地盤上試験 (その8)共掁 ・位相曲線亡動的地盤ばね(B1,B2,B3試験)", pp.1385 - 1386, 日本建築学会大会学術講演梗概集, 1990

4) 犬飼伴幸他, "原子炉建屋の理込み震動効果試験・実地盤上試験 (その11)共振・位相曲線亡動的地盤ばね(D1,D2試験)", pp.1391 - 1392, 日本建築学会大会学術講演梗概集, 1990
5) 藤森健史他, "原子炉建屋の埋込子震動効果試験・実地盤上試験 (その 14)共振 - 位相曲線と動的地盤ばね(C1,C2,C3試験)", pp.1493-1494, 日本建筑学会大会学術講演梗概集, 1992

6) 福岡篤佰他, "杭支持高層建物の地震時挙動 - (その2) 相互作 用効果の検討と建物応答解析-", pp.561-562, 日本建筑学会大 会学術講演梗概集, 1994

7）藤森健史他, "地震時土圧波形による建築構造物への入力地霞動評 価法に関する検討", pp.627-628, 日本建築学会大会学虮講演梗 概集, 1994

8) Luco,J.,E., "On the Relation between Radiation and Scattering Problems for Foundations Embedded in an Elastic Half-space", Soil Dynamics and Earthquake Engineering, Vol. 5, pp.97 101,1986

9) Iguchi,M., "An Approximate Analysis of Input Motions for Rigid Embedded Foundations", Trans. of A. 1. J., No. 315, pp. $61-75,1982$

10) Mal,A.K. and Singh,S.,J., "Deformation of Elastic Solid", Prentice Hall, p.99, 1991

11) 大橋戔夫他訳, "固体の力学/理論", pp.60-62, 培風館

12) Fujimori,T. et al., "Seismic Responses of Embedded Structures (Embedment Effect Tests on Soil-structure Interaction)", Proc. 12th SMiRT, Vol. K1, pp.55 - 60, 1993

13) Kurimoto,O. et al., "Input Motions for Rigid Foundations to Observed Seismic Waves", Proc. 13th SMiRT(Submitted)

14) Wong,H.,L. and Luco,J.,E., "Dynamic Response of Rectangular Foundations to Obliquely Incident Seismic Waves", Earthquake Engineering and Structural Dynamics, Vol. 6, pp.3 - 16, 1978

15) Luco,J.,E. and Wong,H.,L., "Seismic Response of Foundations Embedded in a Layered Half-space", Earthquake Engineering and Structural Dynamics, Vol. 15, pp.233 - 247, 1987

（1994年10月 7 日原稿受理，1995年 4 月25日探用決定） 